\title{
Electron Shuttles Enhance Anaerobic Ammonium Oxidation Coupled to Iron(III) Reduction
}

\author{
Guo-Wei Zhou, ${ }^{\dagger,+}$ Xiao-Ru Yang, ${ }^{*}{ }^{\dagger}$ Hu Li, ${ }^{\dagger,}$ Christopher W. Marshall, ${ }^{\|, \perp}$ Bang-Xiao Zheng, ${ }^{\dagger, \dagger}$ Yu Yan, ${ }^{\dagger, \ddagger}$ \\ Jian-Qiang $\mathrm{Su}^{\dagger}{ }^{\dagger}$ and Yong-Guan $\mathrm{Zhu}^{\dagger, \S}$ \\ ${ }^{\dagger}$ Key Lab of Urban Environment and Health, Institute of Urban Environment, Chinese Academy of Sciences, Xiamen 361021, \\ People's Republic of China \\ ${ }^{\ddagger}$ University of Chinese Academy of Sciences, Beijing 100049, People’s Republic of China \\ ${ }^{\S}$ State Key Lab of Urban and Regional Ecology, Research Center for Eco-Environmental Sciences, Chinese Academy of Sciences, \\ Beijing 100085, People's Republic of China \\ "Department of Surgery, University of Chicago, Chicago Illinois 60637, United States \\ ${ }^{\perp}$ Biosciences Division, Argonne National Laboratory, 9700 South Cass Avenue Lemont, Illinois 60439, United States
}

\section{Supporting Information}

ABSTRACT: Anaerobic ammonium oxidation coupled to iron(III) reduction, termed Feammox, is a newly discovered nitrogen cycling process. However, little is known about the roles of electron shuttles in the Feammox reactions. In this study, two forms of $\mathrm{Fe}$ (III) (oxyhydr)oxide ferrihydrite (ex situ ferrihydrite and in situ ferrihydrite) were used in dissimilatory $\mathrm{Fe}$ (III) reduction (DIR) enrichments from paddy soil. Evidence for Feammox in DIR enrichments was demonstrated using the ${ }^{15} \mathrm{~N}$-isotope tracing technique. The extent and rate of both the ${ }^{30} \mathrm{~N}_{2}-{ }^{29} \mathrm{~N}_{2}$ and $\mathrm{Fe}$ (II) formation were enhanced when amended with electron shuttles (either 9,10anthraquinone-2,6-disulfonate (AQDS) or biochar) and further simulated when these two shuttling compounds were

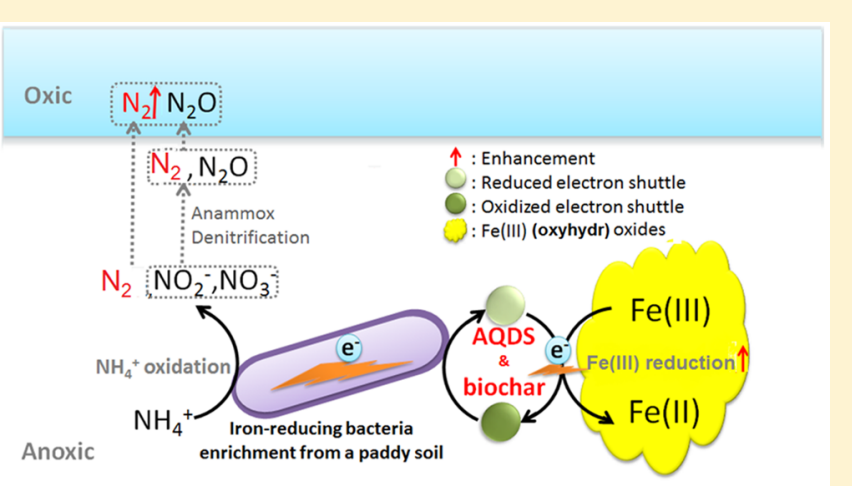
combined. Although the Feammox-associated Fe(III) reduction accounted for only a minor proportion of total Fe(II) formation compared to DIR, it was estimated that the potentially Feammox-mediated N loss $\left(0.13-0.48 \mathrm{mg} \mathrm{N} \mathrm{L}^{-1}\right.$ day $\left.^{-1}\right)$ was increased by $17-340 \%$ in the enrichments by the addition of electron shuttles. The addition of electron shuttles led to an increase in the abundance of unclassified Pelobacteraceae, Desulfovibrio, and denitrifiers but a decrease in Geobacter. Overall, we demonstrated a stimulatory effect of electron shuttles on Feammox that led to higher $\mathrm{N}$ loss, suggesting that electron shuttles might play a crucial role in Feammox-mediated $\mathrm{N}$ loss from soils.

\section{INTRODUCTION}

Nitrogen $(\mathrm{N})$ is one of the limiting factors for primary productivity in terrestrial ecosystems. ${ }^{1-3} \mathrm{~N}$ fertilizers have been applied intensively in paddy soils to promote food production for decades, but the excessive application of $\mathrm{N}$ fertilizers has decreased the $\mathrm{N}$-utilization efficiency. The decrease in efficiency leads to increased $\mathrm{N}$ loss to the environment, causing many environmental problems such as air and water pollution., ${ }^{2,4-6}$ Several anaerobic pathways contribute to $\mathrm{N}$ loss in terrestrial ecosystems, including denitrification, codenitrification, and anaerobic ammonium oxidation (anammox). ${ }^{2,3}$ It was recently reported that anammox could be coupled to iron(III) reduction (termed Feammox) with $\mathrm{N}_{2}, \mathrm{NO}_{2}^{-}$, or $\mathrm{NO}_{3}{ }^{-}$as the endproducts. $^{4-7}$ The following three equations and accompanying free energies summarize these three end routes of Feammox $\left(\Delta_{\mathrm{r}} G_{\mathrm{m}}\right.$ represents the energy yielded from the balanced redox reaction). ${ }^{4-7}$

$$
\begin{aligned}
& 3 \mathrm{Fe}(\mathrm{OH})_{3}+5 \mathrm{H}^{+}+\mathrm{NH}_{4}^{+} \rightarrow 3 \mathrm{Fe}^{2+}+9 \mathrm{H}_{2} \mathrm{O}+0.5 \mathrm{~N}_{2} \Delta_{\mathrm{r}} G_{\mathrm{m}} \\
&=-245 \mathrm{~kJ} \mathrm{~mol}^{-1} \\
& 6 \mathrm{Fe}(\mathrm{OH})_{3}+10 \mathrm{H}^{+}+\mathrm{NH}_{4}^{+} \rightarrow 6 \mathrm{Fe}^{2+}+16 \mathrm{H}_{2} \mathrm{O}+\mathrm{NO}_{2}{ }^{-} \Delta_{\mathrm{r}} G_{\mathrm{m}} \\
&=-164 \mathrm{~kJ} \mathrm{~mol}^{-1} \\
& 8 \mathrm{Fe}(\mathrm{OH})_{3}+14 \mathrm{H}^{+}+\mathrm{NH}_{4}^{+} \rightarrow 8 \mathrm{Fe}^{2+}+21 \mathrm{H}_{2} \mathrm{O}+\mathrm{NO}_{3}{ }^{-} \Delta_{\mathrm{r}} G_{\mathrm{m}} \\
&=-207 \mathrm{~kJ} \mathrm{~mol}^{-1}
\end{aligned}
$$

The first equation could occur energetically in a wide $\mathrm{pH}$ range, and the second and third reactions consume more Fe(III) but conserve less energy and exist only below $\mathrm{pH} 6.5 .^{5}$

Received: April 26, 2016

Revised: July 5, 2016

Accepted: August 5, 2016

Published: August 5, 2016 
Feammox has been detected in freshwater, marine, wetland, tropical forest, paddy soils, and even wastewater ecosystems. ${ }^{7-9}$ It has been demonstrated that Feammox coupled to direct reduction to $\mathrm{N}_{2}$ is the predominant mechanism of the three possible microbial pathways responsible for gaseous $\mathrm{N}$ loss from tropical forests, paddy soils, and intertidal wetlands. ${ }^{7-9}$ Conservative estimation indicated that Feammox metabolizes $7.8-61\left(3.9-31 \%\right.$ of $\mathrm{N}$ fertilizer loss) and $1-4 \mathrm{~kg} \mathrm{NH}_{4}{ }^{+}-\mathrm{N} \mathrm{ha}^{-1}$ year $^{-1}$ in paddy soil and upland surface soil, respectively. ${ }^{4,5}$ Thus, due to the abundance of $\mathrm{Fe}$ (III) (oxyhydr)oxides in most soils and the detrimental effects of $\mathrm{N}_{2}$ loss through Feammox, it is important to study the mechanism of iron(III) reduction coupled to ammonium oxidation by Feammox bacteria.

In addition to direct contact, bacterial nanowires, and Fe(III) complexation, electron shuttling also has been suggested to contribute to $\mathrm{Fe}(\mathrm{III})$ reduction. ${ }^{10-14}$ Electron shuttles, including humic substances and biochar, have been reported to facilitate electron transfer between a wide range of microbes and $\mathrm{Fe}(\mathrm{III})$ (oxyhydr)oxides, enhancing microbial iron(III) reduction and $\mathrm{Fe}$ cycling in soils. ${ }^{10-14}$ In many electron shuttles, quinone moieties are the redox-active components for electron transfer. ${ }^{10-14}$ Humic substances are quinone-rich and ubiquitous in the environment, accounting for up to $10 \%$ in soils. ${ }^{15}$ Biochar also possesses quinone structures. It has been demonstrated to enhance soil fertility and to be an effective electron shuttle for iron(III) reduction. ${ }^{16} \mathrm{We}$ thus hypothesize that humic substances and biochar act as electron shuttles to facilitate the transfer of electrons from $\mathrm{NH}_{4}^{+}$toward solid $\mathrm{Fe}(\mathrm{III})$ (oxyhydr)oxides and that this is mediated by Feammox bacteria, ultimately leading to an increase in $\mathrm{N}$ loss from the system. Published methods for ${ }^{15} \mathrm{~N}$ and ${ }^{14} \mathrm{~N}$ analysis of $\mathrm{N}_{2}$ have been reported as a powerful tool to track the $\mathrm{N}$ cycle and pathways in the study of Feammox. ${ }^{4-6}$ Culture studies have shown that ${ }^{30} \mathrm{~N}_{2}$ could be produced through four different pathways in the anoxic environment. ${ }^{4,5}$ Under these conditions, ${ }^{30} \mathrm{~N}_{2}$ directly results from Feammox or Feammox-generated ${ }^{15} \mathrm{NO}_{2}{ }^{-}$and ${ }^{15} \mathrm{NO}_{3}{ }^{-}$followed by anammox, denitrification, or chemodenitrification-based denitrification (Table 1). ${ }^{4,5,17,18}$ Also, several pathways detailed in the following table make contribution to ${ }^{29} \mathrm{~N}_{2}$ production, but all of the pathways first required the anaerobic oxidation of ammonium.

To address this hypothesis, enrichments for dissimilatory iron(III)-reducing bacteria (DIRB) with poorly crystalline amorphous ferrihydrite as the electron acceptor were established. A total of two forms of ferrihydrite (ex situ ferrihydrite and in situ ferrihydrite) produced by different procedures were used. Quinone compound 9,10-anthraquinone-2,6-disulfonate (AQDS), which is a model compound for quinone moieties in humic substances, and biochar were added to the enrichment cultures to investigate the impact of electron shuttles on Feammox. With the use of a ${ }^{15} \mathrm{NH}_{4}^{+}$-based isotopic tracing technique and $16 \mathrm{~S}$ rRNA gene-based amplicon sequencing, the main objectives of this study were to (i) demonstrate the existence of microbially mediated Feammox, (ii) quantitatively determine the impact of electron shuttles on the extent and rate of Feammox in different iron(III)-reducing enrichments, and (iii) characterize the shift in the Feammox-related bacterial community and confirm the microbial role in Feammox.

\section{MATERIALS AND METHODS}

Characterization of Biochar. Biochar used in experiments was produced from air-dried rice stalks via slow pyrolysis at $500{ }^{\circ} \mathrm{C}$ for $4 \mathrm{~h}$ in a muffle furnace (Isotemp, Fisher Scientific, Waltham, MA) purged with $\mathrm{N}_{2}$. Biochar was sieved (pore size $0.15 \mathrm{~mm}$ ) and washed three times with deionized water before application. The basic properties of biochar are shown in Table S1.

DIRB Enrichments Cultivation. Paddy soil was collected from Yingtan $\left(116^{\circ} 82^{\prime} \mathrm{N}, 28^{\circ} 2^{\prime} \mathrm{E}\right)$, Jiangxi Province, China. It is a typical acidic red soil containing a high level of $\mathrm{Fe}(\mathrm{III})$ (oxyhydr)oxide but a low level of organic carbon in South China, which may be readily for iron(III)-reducing bacteria enrichment. The basic properties of soil were detailed in Table S2. Anaerobic incubations were prepared by mixing $3 \mathrm{~g}$ of fresh soil into $50 \mathrm{~mL}$ of anoxic distilled water with shaking at $120 \mathrm{rpm}$ for $2 \mathrm{~h}$ at $25^{\circ} \mathrm{C}$. Aliquots $(2 \mathrm{~mL})$ of the soil slurry were transferred into $50 \mathrm{~mL}$ serum vials with $20 \mathrm{~mL}$ of sterilized (autoclaved, $120{ }^{\circ} \mathrm{C}$ for $20 \mathrm{~min}$ ) anoxic medium and incubated at $25{ }^{\circ} \mathrm{C}$ in the dark. The basal medium ( $\mathrm{pH} 6.8-7.2)$ contains $\mathrm{MgCl}_{2} \cdot 6 \mathrm{H}_{2} \mathrm{O}$ $\left(0.4 \mathrm{~g} \mathrm{~L}^{-1}\right), \mathrm{CaCl}_{2} \cdot \mathrm{H}_{2} \mathrm{O}\left(0.1 \mathrm{~g} \mathrm{~L}^{-1}\right), \mathrm{NH}_{4} \mathrm{Cl}\left(0.027 \mathrm{~g} \mathrm{~L}^{-1}\right)$, and $\mathrm{KH}_{2} \mathrm{PO}_{4}\left(0.6 \mathrm{~g} \mathrm{~L}^{-1}\right), 1 \mathrm{~mL} \mathrm{~L}^{-1}$ vitamin solution, ${ }^{21} 1 \mathrm{~mL} \mathrm{~L}^{-1}$ trace element solutions, ${ }^{21}$ and $30 \mathrm{mmol} \mathrm{L}^{-1}$ bicarbonate buffer. Ferrihydrite and acetate were added at final concentrations of 10 and $2 \mathrm{mmol} \mathrm{L}^{-1}$, respectively. The headspace of the medium was flushed with $\mathrm{N}_{2}$ and $\mathrm{CO}_{2}(80 / 20 \%)$. In our study, two forms of ferrihydrite, ex situ ferrihydrite and in situ ferrihydrite, were used. The amount of ex situ ferrihydrite added to cultures was calculated using the formula of $\mathrm{Fe}_{5} \mathrm{HO}_{8} \cdot 4 \mathrm{H}_{2} \mathrm{O}$, which was synthesized according to Schwertmann and Cornell. ${ }^{22,23}$ The in situ ferrihydrite was formed by adding iron(III) chloride to the medium and adjusting the $\mathrm{pH}$ of the medium to 6.8-7.2. The basal media, in situ ferrihydrite and ex situ ferrihydrite were autoclaved $\left(120{ }^{\circ} \mathrm{C}\right.$ for $\left.20 \mathrm{~min}\right)$ before inoculation. The vitamin solution, trace element solution, and acetate from stock solutions were filtrated with $0.22 \mu \mathrm{m}$ filter and added into the sterilized media, respectively.

Experimental Setup. To investigate the effect of electron shuttles on Feammox, six treatments $(n=3$ each) were set

Table 1. Possible Pathways for ${ }^{30} \mathrm{~N}_{2}$ and ${ }^{29} \mathrm{~N}_{2}$ Production from ${ }^{15} \mathrm{NH}^{4+}$ under Anoxic Conditions (Modified from Ding et al. and Yang et al. $)^{4,5}$

\begin{tabular}{cl} 
product & \multicolumn{1}{c}{ nitrogen 1} \\
${ }^{30} \mathrm{~N}_{2}$ & ${ }^{15} \mathrm{NH}_{4}{ }^{+}$(added) \\
& ${ }^{15} \mathrm{NH}_{4}{ }^{+}$(added) \\
& ${ }^{15} \mathrm{NO}_{2}^{-}$and ${ }^{15} \mathrm{NO}_{3}^{-}$(Feammox) \\
& ${ }^{15} \mathrm{NO}_{2}^{-}$and ${ }^{15} \mathrm{NO}_{3}^{-}$(Feammox) \\
${ }^{29} \mathrm{~N}_{2}$ & ${ }^{15} \mathrm{NH}_{4}^{+}$(added) \\
& ${ }^{15} \mathrm{NH}_{4}^{+}$(added) \\
& ${ }^{15} \mathrm{NO}_{2}^{-}$and ${ }^{15} \mathrm{NO}_{3}^{-}$(Feammox) \\
& ${ }^{15} \mathrm{NO}_{2}^{-}$and ${ }^{15} \mathrm{NO}_{3}^{-}$(Feammox $)$ \\
& ${ }^{15} \mathrm{NO}_{2}^{-}$and ${ }^{15} \mathrm{NO}_{3}^{-}$(Feammox)
\end{tabular}

\author{
nitrogen 2 \\ ${ }^{15} \mathrm{NH}_{4}^{+}$(added) \\ ${ }^{15} \mathrm{NO}_{2}^{-}$and ${ }^{15} \mathrm{NO}_{3}^{-}$(Feammox) \\ ${ }^{15} \mathrm{NO}_{2}^{-}$and ${ }^{15} \mathrm{NO}_{3}^{-}$(Feammox) \\ ${ }^{15} \mathrm{NO}_{2}{ }^{-}$and ${ }^{15} \mathrm{NO}_{3}{ }^{-}$(Feammox) \\ ${ }^{14} \mathrm{NH}_{4}^{+}$(indigenous) \\ ${ }^{14} \mathrm{NO}_{2}^{-}$and ${ }^{14} \mathrm{NO}_{3}^{-}$(indigenous) \\ ${ }^{14} \mathrm{NO}_{2}{ }^{-}$and ${ }^{14} \mathrm{NO}_{3}{ }^{-}$(indigenous) \\ amino compounds (indigenous) \\ ${ }^{14} \mathrm{NO}_{2}^{-}$and ${ }^{14} \mathrm{NO}_{3}{ }^{-}$(indigenous)
}

process

Feammox to $\mathrm{N}_{2}$

anammox

denitrification ${ }^{17,19}$

chemodenitrification ${ }^{18,20}$ and denitrification

Feammox to $\mathrm{N}_{2}$

anammox

denitrification

codenitrification $^{17,19}$

chemodenitrification $^{18,20}$ and denitrification 
up: (1) abiotic treatment inoculated with sterilized (autoclaved, $120{ }^{\circ} \mathrm{C}$ for $20 \mathrm{~min}$ ) DIRB inoculum (named as CK abiotic); (2) biotic treatment inoculated with live DIRB inoculum (CK biotic); (3) biotic treatment amended with $500 \mu \mathrm{mol} \mathrm{L}{ }^{-1} \mathrm{AQDS}$ (AQDS biotic); (4) biotic treatment amended with $2.5 \mathrm{~g} \mathrm{~L}^{-1}$ biochar (biochar biotic); (5) biotic treatment amended with $500 \mu \mathrm{mol} \mathrm{L} \mathrm{L}^{-1} \mathrm{AQDS}$ and $2.5 \mathrm{~g} \mathrm{~L}^{-1}$ biochar simultaneously (AQDS + biochar biotic); and (6) abiotic treatment amended with $500 \mu \mathrm{mol} \mathrm{L}-1$ AQDS and $2.5 \mathrm{~g} \mathrm{~L}^{-1}$ biochar simultaneously (AQDS + biochar abiotic). The DIRB enrichments were transferred $(10 \%, \mathrm{v} / \mathrm{v})$ to fresh medium monthly for four generations before the start of the six treatments. The isotope tracing experiments were initiated by inoculating $2 \%(\mathrm{v} / \mathrm{v})$ wellmixed DIRB enrichment cultures into $20 \mathrm{~mL}$ of fresh medium in which the ${ }^{14} \mathrm{NH}_{4} \mathrm{Cl}$ was replaced by ${ }^{15} \mathrm{NH}_{4} \mathrm{Cl}\left(0.5 \mathrm{mmol} \mathrm{L}^{-1}\right.$; ${ }^{15} \mathrm{~N}$, 99 atom \%; Cambridge Isotope Laboratories, Andover, $\mathrm{MA}$ ), and the vitamin solution was omitted to avoid unwanted electron transfer reactions. The headspace of the labeled medium was flushed with ultrapure helium instead of nitrogen gas. The biochar was washed before use, and AQDS solution was filtrated with a $0.22 \mu \mathrm{m}$ filter from stock solution prior to the addition.

Chemical Analyses. Ferrous iron $[\mathrm{Fe}(\mathrm{II})]$ and total $\mathrm{Fe}$ were measured as described by Klueglein and Kappler. ${ }^{24}$ Briefly, for $\mathrm{Fe}(\mathrm{II})$ determination, $100 \mu \mathrm{L}$ of culture suspension was transferred anaerobically with a syringe into $900 \mu \mathrm{L}$ of $40 \mathrm{mmol} \mathrm{L}^{-1}$ sulfamic acid for $1 \mathrm{~h}$ of incubation at room temperature. Total Fe was extracted with $20 \mathrm{mmol} \mathrm{L}^{-1}$ hydroxylamine hydrochloride in $20 \mathrm{mmol} \mathrm{L}^{-1}$ sulfamic acid. A total of $100 \mu \mathrm{L}$ of extract was transferred to $10 \mathrm{~mL}$ of ferrozine solution ( $1 \mathrm{~g}$ of ferrozine in $50 \mathrm{mmol} \mathrm{L}^{-1}$ HEPES buffer, $\mathrm{pH}=7$ ) to form the ferrous complex. The complex was quantified at $562 \mathrm{~nm} \mathrm{UV-vis} \mathrm{spectrometer.} \mathrm{Iron(III)} \mathrm{reduction}$ rates were calculated from the linear change in $\mathrm{Fe}$ (II) concentrations between two given time points. The concentrations of acetate, $\mathrm{NH}_{4}^{+}, \mathrm{NO}_{3}^{-}$, and $\mathrm{NO}_{2}^{-}$were measured by ion chromatography (Dionex ICS-3000 system; Diones, Sunnyvales, CA). Liquid samples were taken in the anoxic glovebox and filtered through $0.22 \mu \mathrm{m}$ filters. $\mathrm{pH}$ was determined with a dual-channel $\mathrm{pH}$-ion-conductivity-dissolved oxygenmeter (X60, Fisher Scientific). Total organic carbon (TOC) was determined with a TOC analyzer (Shimadzu TOC-Vcph, Japan) with a solid sample module (SSM-5000A), and C, N, and $S$ with an elemental analyzer (Vario MAX CNS, Germany). Extractable major and trace metal concentrations were digested using a strong acid digestion method ${ }^{25}$ and measured with inductively coupled plasma optical emission spectrometry (ICP-OES; Optima, 7000DV; PerkinElmer) and inductively coupled plasma mass spectrometry (ICP-MS; $7500 \mathrm{cx}$; Agilent Technologies, Inc., Tokyo, Japan).

Headspace $\mathrm{N}_{2}$ concentration was analyzed using a robotized sampling and analyzing system (GC-TCD 7890, Aglient Technologies). ${ }^{26}$ For tje analysis of ${ }^{15} \mathrm{~N}-\mathrm{N}_{2}, 1 \mathrm{~mL}$ gas samples were collected every 3 days by gas-tight syringes and then injected into $12 \mathrm{~mL}$ glass vials (Exetainer, Labco) full of ultrapure helium. The ratio of ${ }^{15} \mathrm{~N}$ in total $\mathrm{N}_{2}$ was measured by GC-isotope ratio mass spectrometry (Thermo Finnigan Delta $\mathrm{V}$ Advantage, Bremen, Germany) as described previously. ${ }^{27}$ ${ }^{15} \mathrm{~N}-\mathrm{N}_{2}$ concentration was calculated as the product of $\mathrm{N}_{2}$ and ${ }^{15} \mathrm{~N}-\mathrm{N}_{2}$ atom percent excess above its natural abundance. Gas production rate was calculated from the linear change of gas concentrations in the headspace between two given time points.
Bacterial 16S rRNA Gene Amplification, Illumina Sequencing, and Data Processing. After a 30 day incubation, FastDNA Spin Kit (MP Biomedical, France) was used to extract DNA from the samples (harvested by centrifugation; $14000 \mathrm{~g}, 15 \mathrm{~min}$ ) according to the manufacturer's protocol. The V4 and V5 regions of bacterial 16S rRNA genes were amplified using the DNA extracted from the samples as template. The forward primer was 515F (5'-GTGCCAGCMGCCGCGG-3'), and the reverse primer consisted of a six bp barcode and 907R (5'- CCGTCAATTCMTTTRAGTTT-3') ${ }^{28}$ The amplicons were purified, quantified, pooled, and then sequenced on an Illumina Miseq PE 250 platform at Novogene, Beijing, China. ${ }^{29}$ Sequences were processed and analyzed using Quantitative Insights Into Microbial Ecology (QIIME). ${ }^{30}$ The open-reference operational taxonomic unit (OTU) picking was performed after removing any low-quality or ambiguous reads according to the online instruction of QIIME. ${ }^{31}$ The OTU was defined at $97 \%$ similarity level using UCLUST clustering. ${ }^{31}$ The most-abundant sequence from each OTU was selected as the representative sequence, which was assigned to taxonomy using an RDP classifier. ${ }^{31}$ The differences between microbial communities were investigated by nonmetric multidimensional scaling (NMDS), which was based on weighted UniFrac dissimilarity among samples. ${ }^{32,33}$ The ordination axes explain variance in the dissimilarities. ${ }^{33}$

Statistical Analyses. Statistical tests, which included analysis of variance (ANOVA) and Pearson correlation analysis, were performed using SPSS 18.0 (SPSS Inc., Chicago, IL) and Origin 9.0 (Inc., OriginLab, Northampton, MA). Statistical significance was determined by Duncan's multiple range test and denoted at $P<0.05$.

Data Accessibility. The 16S rRNA gene sequences have been deposited in GenBank with accession number SRX1618418.

\section{RESULTS}

${ }^{30} \mathrm{~N}_{2}$ and ${ }^{29} \mathrm{~N}_{2}$ Production, Total $\mathrm{NH}_{4}^{+}$Removal, and $\mathrm{NO}_{3}{ }^{-}$and $\mathrm{NO}_{2}{ }^{-}$Formation from DIRB Enrichments. The concentrations of ${ }^{30} \mathrm{~N}_{2}$ in the treatment of AQDS reached a maximum of 15.48 and $5.32 \mu \mathrm{mol} \mathrm{L} \mathrm{L}^{-1}$, which represented a $319 \%$ and $48 \%$ increase compared to the results from the nonamended controls in the ex situ ferrihydrite $\left(3.69 \mu \mathrm{mol} \mathrm{L} \mathrm{L}^{-1}\right.$ in the $\mathrm{CK}$ biotic) and in situ ferrihydrite enrichments (3.59 $\mu \mathrm{mol} \mathrm{L}^{-1}$ in the CK biotic), respectively (Figure 1A,D and Table S3). After biochar addition, ${ }^{30} \mathrm{~N}_{2}$ production extent increased $17 \%$ and $94 \%$ compared to results from nonamended controls after a 30 day incubation in ex situ ferrihydrite and in situ ferrihydrite enrichments, respectively (Figure 1A,D and Table S3). AQDS with biochar also significantly $(P<0.05)$ stimulated the rate of ${ }^{30} \mathrm{~N}_{2}$ production extent in both enrichments (Figure 1C,F). Moreover, the extent and rate of ${ }^{30} \mathrm{~N}_{2}$ production in the enrichment amended with both AQDS and biochar was significantly $(P<0.05)$ higher than those amended with AQDS or biochar alone in the in situ ferrihydrite enrichment but not in the ex situ ferrihydrite enrichment (Figure 1A,C,D,F and Table S3). In comparison with ${ }^{30} \mathrm{~N}_{2}$ accumulation, greater ${ }^{29} \mathrm{~N}_{2}\left({ }^{14} \mathrm{~N}^{15} \mathrm{~N}\right)$ formation was observed in all biotic treatments (Figure 1B,E). The ratios of ${ }^{30} \mathrm{~N}_{2}$ and ${ }^{29} \mathrm{~N}_{2}$ ranged from 2.9 to 7.8 in the enrichments (Table S4). The kinetics of ${ }^{29} \mathrm{~N}_{2}$ production extents and rates shared similar trends with that of ${ }^{30} \mathrm{~N}_{2}$ production in the both enrichments (Figure 1B-E and Table S3). In addition, amendment with AQDS had a much-greater impact on the extent and rate of $\mathrm{N}_{2}$ production than that of biochar amendment in the ex situ 

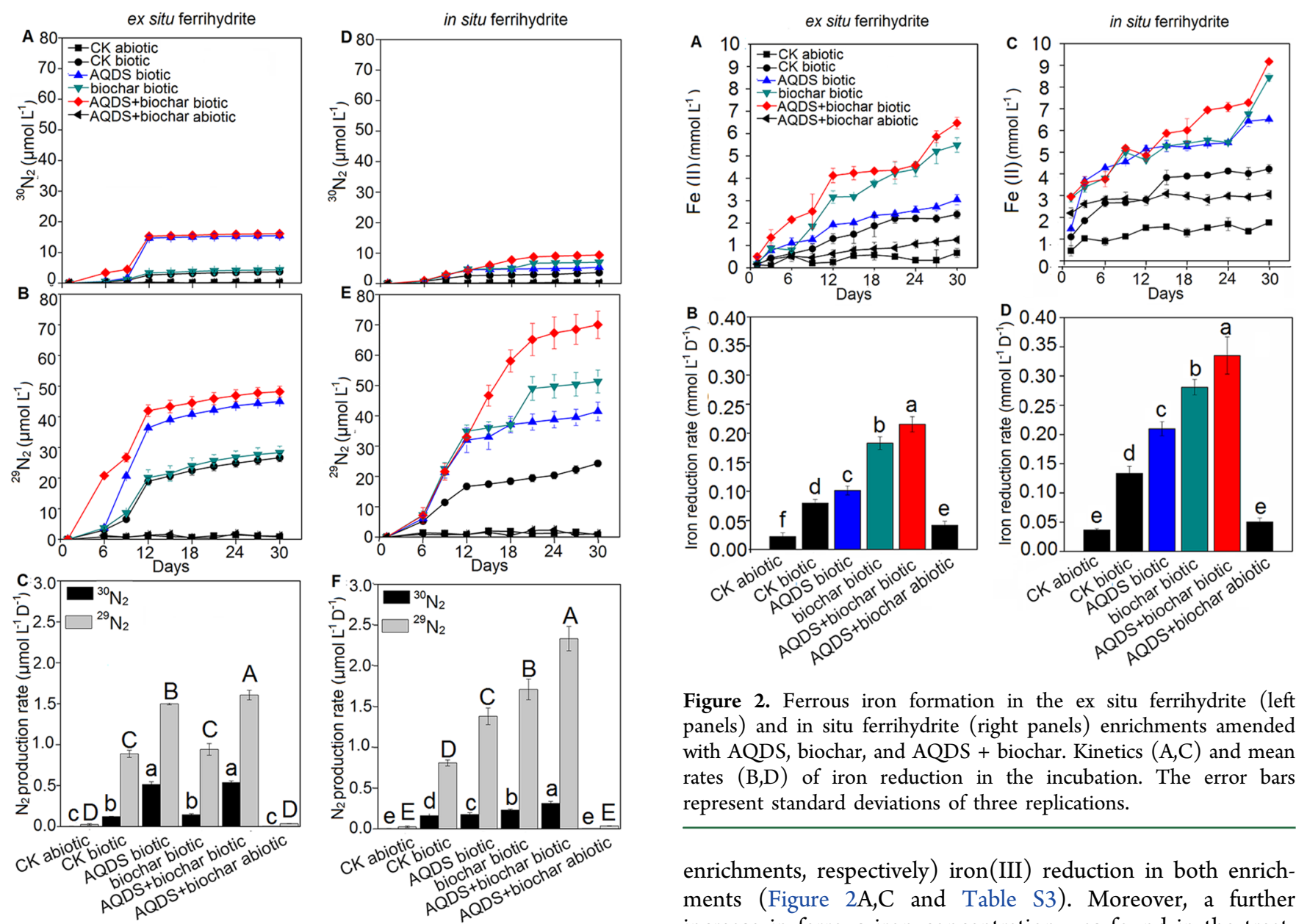

Figure 2. Ferrous iron formation in the ex situ ferrihydrite (left panels) and in situ ferrihydrite (right panels) enrichments amended with AQDS, biochar, and AQDS + biochar. Kinetics $(\mathrm{A}, \mathrm{C})$ and mean rates $(\mathrm{B}, \mathrm{D})$ of iron reduction in the incubation. The error bars represent standard deviations of three replications.

Figure 1. ${ }^{30} \mathrm{~N}_{2}$ and ${ }^{29} \mathrm{~N}_{2}$ production in the ex situ ferrihydrite (left panels) and in situ ferrihydrite (right panels) enrichments amended with AQDS, biochar, and AQDS + biochar. Kinetics $(\mathrm{A}, \mathrm{B}, \mathrm{D}, \mathrm{E})$ and mean rates $(C, F)$ of headspace ${ }^{30} \mathrm{~N}_{2}$ and ${ }^{29} \mathrm{~N}_{2}$ production. The error bars represent standard deviations of three replications.

ferrihydrite enrichment, and biochar showed greater enhancement than did AQDS in the in situ ferrihydrite enrichment (Figure 1 and Table S3).

The concentration of total $\mathrm{NH}_{4}^{+}$decreased, resulting in larger $\mathrm{NH}_{4}{ }^{+}$consumption when amended with electron shuttles (210-300 $\mu \mathrm{mol} \mathrm{\textrm {L } ^ { - 1 }}$ ) compared with results from the CK setups $\left(150-160 \mu \mathrm{mol} \mathrm{L}^{-1}\right)$ in both of the ferrihydrite enrichments after 30 days of incubation (Figure $\mathrm{S} 1$ ). The $\mathrm{NO}_{3}{ }^{-}$and $\mathrm{NO}_{2}{ }^{-}$concentrations also decreased $\left(1-13 \mu \mathrm{mol} \mathrm{L}{ }^{-1}\right.$ for $\mathrm{NO}_{3}{ }^{-}$ and $14-22 \mu \mathrm{mol} \mathrm{L}{ }^{-1}$ for $\left.\mathrm{NO}_{2}^{-}\right)$in all of the biotic setups in ex situ ferrihydrite enrichment (Figure $\mathrm{S} 1$ ). However, for the in situ ferrihydrite enrichments, the $\mathrm{NO}_{3}{ }^{-}$and $\mathrm{NO}_{2}{ }^{-}$concentrations were decreased $\left(1.5-6.7 \mu \mathrm{mol} \mathrm{L}^{-1}\right.$ for $\mathrm{NO}_{3}^{-}$and 30-32 $\mu \mathrm{mol} \mathrm{L} \mathrm{L}^{-1}$ for $\left.\mathrm{NO}_{2}^{-}\right)$in the AQDS amendment but increased $\left(1-15 \mu \mathrm{mol} \mathrm{L}^{-1}\right.$ for $\mathrm{NO}_{3}^{-}$and $15-22 \mu \mathrm{mol} \mathrm{L}{ }^{-1}$ for $\mathrm{NO}_{2}^{-}$) in the biochar and biochar + AQDS amendments (Figure S1).

Iron(III) Reduction in DIRB Enrichments. The final concentration of ferrous iron(II) was increased by $16 \%$ and $54 \%$ in the AQDS amendments compared to the CK biotic after a 30 day incubation in the ex situ ferrihydrite and in situ ferrihydrite enrichments, respectively (Figure 2A,C and Table S3). Biochar also significantly $(P<0.05)$ increased (by $130 \%$ and $100 \%$ in the ex situ ferrihydrite and in situ ferrihydrite

enrichments, respectively) iron(III) reduction in both enrichments (Figure 2A,C and Table S3). Moreover, a further increase in ferrous iron concentration was found in the treatment of AQDS and biochar addition in both DIRB enrichments (Figure 2A,C and Table S3). The average rate of iron(III) reduction was also facilitated by amending with AQDS, biochar, or both, showing a similar trend in both enrichments (Figure 2B,D). Additionally, the extent and rate of iron(III) reduction were increased more significantly by biochar addition than those by AQDS addition in both enrichments (Figure 2A-D). Total extractable $\mathrm{Fe}$ in all the treatments remained constant throughout the experiments (Figure S2). Sterilized controls showed low levels of abiotic Fe(III) reduction, which accounted for $6-17.5 \%$ and $12.5-30.4 \%$ of the total $\mathrm{Fe}(\mathrm{III})$ in the treatments of $\mathrm{CK}$ abiotic and (AQDS + biochar) abiotic, respectively (Figure 2A,C).

A linear and positive correlation $(P<0.0001)$ was found between the production rate of ${ }^{30} \mathrm{~N}_{2}$ and ${ }^{29} \mathrm{~N}_{2}$ and the rate of iron(III) reduction among all biotic treatments in the two enrichments (Figure 3). The slope of lines related to ${ }^{30} \mathrm{~N}_{2}$ production shared a similar trend with ${ }^{29} \mathrm{~N}_{2}$ production in the both of the ferrihydrite enrichments (Figure 3). The slope of all treatments in the in situ ferrihydrite enrichment (AQDS biotic > AQDS + biochar biotic $>$ CK biotic $>$ biochar biotic) exhibited a distinct trend from the ex situ ferrihydrite enrichment (AQDS + biochar biotic > biochar biotic > CK biotic > AQDS biotic) (Figure 3C,D).

Proportion of Iron(III) Reduction Associated with Feammox and Dissimilatory Iron(III) Reduction. According to the three eqs $(1-3)$, oxidation of 1 mole of $\mathrm{NH}_{4}^{+}$ could be coupled with reduction of $3-8 \mathrm{~mol}$ of $\mathrm{Fe}$ (III) by microbes. On the basis of this ratio, it was estimated that $0.4-6.1 \%$ of $\mathrm{Fe}(\mathrm{III})$ reduction was associated with Feammox in 

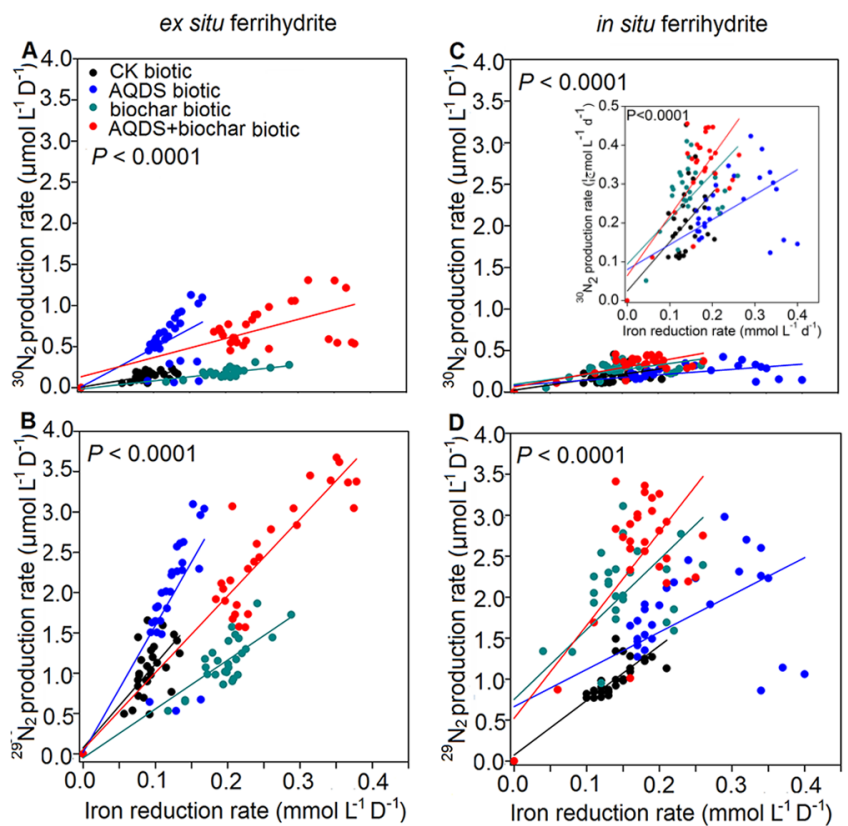

Figure 3. Relationship between iron reduction rates and ${ }^{30} \mathrm{~N}_{2}$ or ${ }^{29} \mathrm{~N}_{2}$ production rates in the ex situ ferrihydrite (left panels) and in situ ferrihydrite (right panels) enrichments amended with AQDS, biochar, and AQDS + biochar. Linear regression was used to test the correlation between the iron reduction rates and ${ }^{30} \mathrm{~N}_{2}$ or ${ }^{29} \mathrm{~N}_{2}$ production rates. $P$ values of all treatments were shown in pictures. $R^{2}$ values (between ${ }^{30} \mathrm{~N}_{2}$ production rates and iron reduction rates) were 0.62 (CK biotic), 0.36 (AQDS biotic), 0.78 (biochar biotic), and 0.46 (AQDS + biochar biotic) in the ex situ ferrihydrite enrichment and 0.40 (CK biotic), 0.38 (AQDS biotic), 0.45 (biochar biotic), and 0.59 (AQDS + biochar biotic) in the in situ ferrihydrite enrichment, respectively. $R^{2}$ values (between ${ }^{29} \mathrm{~N}_{2}$ production rates and iron reduction rates) were 0.62 ( $\mathrm{CK}$ biotic), 0.60 (AQDS biotic), 0.82 (biochar biotic), and 0.88 (AQDS + biochar biotic) in the ex situ ferrihydrite enrichment and 0.82 (CK biotic), 0.37 (AQDS biotic), 0.46 (biochar biotic), and 0.57 (AQDS + biochar biotic) in the in situ ferrihydrite enrichment, respectively.

all biotic ferrihydrite enrichments (Table S5). The major proportion $(57.5-85.8 \%)$ of produced $\mathrm{Fe}$ (II) was coupled to organic matter (acetate et al.) oxidation (Table S5).

Microbial Community in DIRB Enrichments. After 30 days, DNA only obtained from biotic treatments. The number of OTU varied from $965 \pm 76$ to $6280 \pm 408$ per sample, while the sequence number ranged from 59784 to 146120 (Table S6). Nonmetric multidimensional scaling (NMDS) analysis showed that microbial community compositions in the CK biotic, electron shuttle amendments and YT (intact soil) were distinctly clustered (stress value of 0.18 ), respectively (Figure 4A), suggesting that the bacterial community varied with the process of the DIRB enrichment and electron shuttle addition. To understand the observed clustering of the microbial communities, the 28 most-abundant genera were selected from each treatment in both enrichments. In the presence of $\mathrm{Fe}(\mathrm{III})$ (oxyhydr)oxides, the proportion of Geobacter was significantly $(P<0.05)$ increased compared to the intact soil and accounted for $69 \%-88 \%$ of total bacterial community in both shuttle-free enrichments (CK) (Figure 4B), whereas after amendment with AQDS, biochar, or both, a significant $(P<0.05)$ decrease in Geobacter but increase in the unclassified Pelobacteraceae was observed in both enrichments (Figure 4B). Furthermore, amendment with biochar

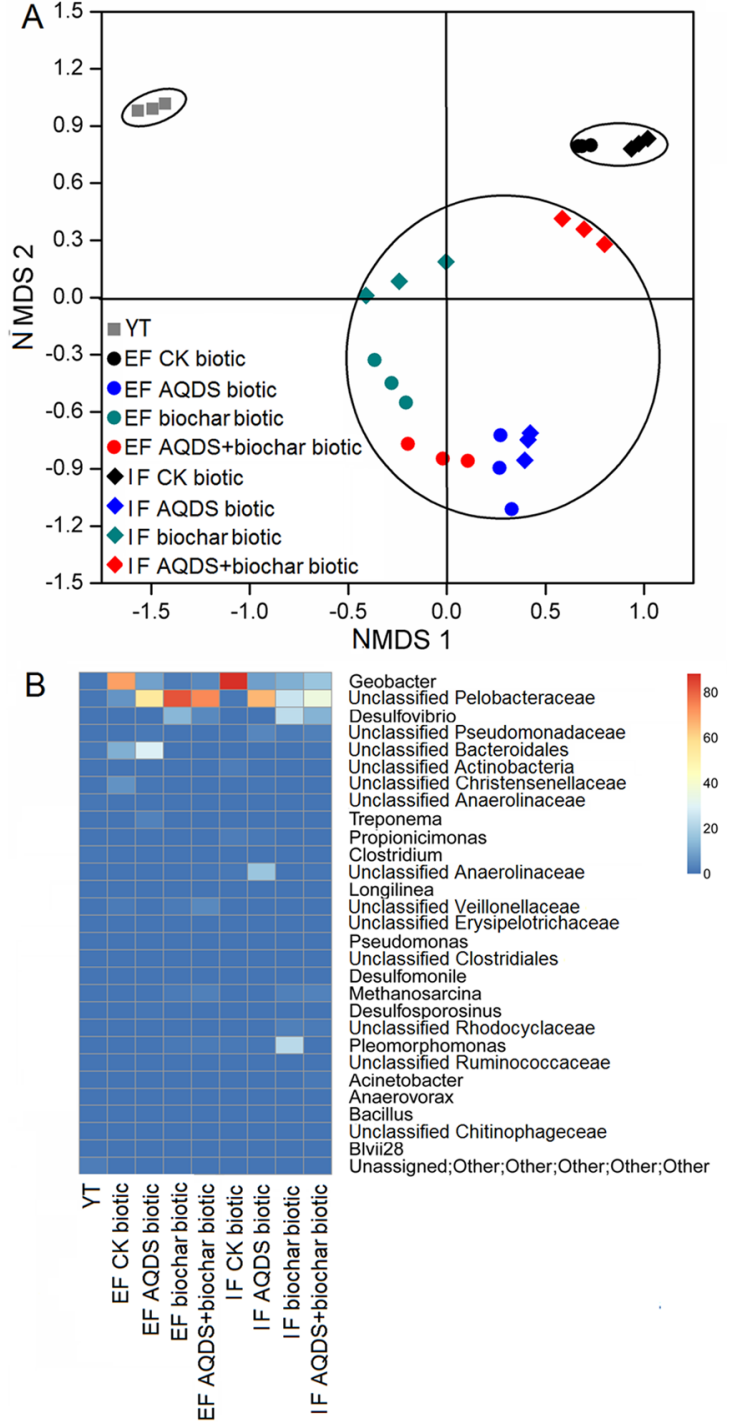

Figure 4. Nonmetric multidimensional scaling (NMDS) analysis of bacterial community (A) and heatmap (B) of the 28 most-abundant genera in each treatment in the ex situ ferrihydrite (EF) and in situ ferrihydrite (IF) enrichments. The stress value of NMDS analysis is shown in the picture. The color intensity of the heatmap in each cell indicates the relative abundance of a genus in a treatment, with a legend presented at the top of the figure; the relative abundance is expressed as the average percentage of the targeted sequences to the total high-quality bacterial sequences of three rRNA fraction samples in each treatment in each enrichment.

significantly $(P<0.05)$ enhanced the abundance of Desulfovibrio (13\% and $20 \%$ in the ex situ ferrihydrite and in situ ferrihydrite enrichments, respectively) (Figure 4B). Additionally, only a minor proportion of other genera, including Clostridium, Desulfosporosinus, and Pseudomonas, were detected out of total bacterial community in all treatments (Figure 4B).

\section{DISCUSSION}

Evidence for the Occurrence of Feammox in the Ferrihydrite Enrichment. After labeled ${ }^{15} \mathrm{NH}_{4}^{+}$was added into the DIRB enrichments, significant ${ }^{30} \mathrm{~N}_{2}$ accumulation in both the ferrihydrite enrichments provided evidence for the occurrence of Feammox (Figure 1). To avoid aerobic nitrification during incubations, all operations were performed under 
strict anoxic conditions throughout the experiments. In addition, codenitrification, which is another potential source of ${ }^{30} \mathrm{~N}_{2}$ and co-occurs with denitrification, can be ruled out in this study because no other ${ }^{15} \mathrm{~N}$-labeled nitrogen compounds (including hydrazine and amino compounds) that could reduce ${ }^{15} \mathrm{NO}_{2}{ }^{-}$ and ${ }^{15} \mathrm{NO}_{3}{ }^{-}$were available in the enrichments. ${ }^{2,4}$ The ratio of $\mathrm{Fe}$ (III) to $\mathrm{NH}_{4}{ }^{+}$in the medium (about 20:1) was sufficient to drive the reaction of Feammox that produced $\mathrm{N}_{2}, \mathrm{NO}_{2}{ }^{-}$, or $\mathrm{NO}_{3}{ }^{-}$according to eqs $1-3$. The positive correlation between the rate of ${ }^{30} \mathrm{~N}_{2}$ production and $\mathrm{Fe}(\mathrm{III})$ reduction provided further proof for the existence of Feammox in both DIRB enrichments (Figure 3). Hence, the accumulation of ${ }^{30} \mathrm{~N}_{2}$ provided solid evidence for the occurrence of Feammox because Feammox played an indispensable role in ${ }^{30} \mathrm{~N}_{2}$ production on the basis of the potential pathways introduced in Table 1 in our incubation system. ${ }^{29} \mathrm{~N}_{2}$ was also accumulated in these two DIRB enrichments, indicating that the medium was well-mixed (Figure 1). ${ }^{5}$ The ${ }^{15} \mathrm{~N}$ atom of ${ }^{29} \mathrm{~N}_{2}$ was undoubtedly from the labeled ${ }^{15} \mathrm{NH}_{4}^{+}$, and the ${ }^{14} \mathrm{~N}$ was potentially derived from the DIRB inoculum or the ${ }^{14} \mathrm{NH}_{4}^{+}$contained by the 99 atom $\%-{ }^{15} \mathrm{NH}_{4} \mathrm{Cl} .{ }^{29} \mathrm{~N}_{2}$ could be produced through a variety of combinations detailed in Table 1 , but all of the pathways first required the anaerobic oxidation of ammonium. Moreover, the ${ }^{29} \mathrm{~N}_{2}$ production rate was significantly correlated with the iron(III) reduction rate $(P<0.0001)$, which further demonstrated the existence of Feammox in DIRB enrichments, leading to more $\mathrm{NH}_{4}{ }^{+}$consumption (Figure 3). The previous studies have shown that substrate molecules containing the lighter ${ }^{14} \mathrm{~N}$ atom are typically consumed at higher rates than the heavier ${ }^{15} \mathrm{~N}$ atom due to the isotopic fraction effect. ${ }^{34-36}$ The higher concentration of ${ }^{29} \mathrm{~N}_{2}$ production than ${ }^{30} \mathrm{~N}_{2}$ suggested that preferential conversion of ${ }^{14} \mathrm{~N}-\mathrm{NH}_{4} \mathrm{Cl}$ and ${ }^{14} \mathrm{~N}-\mathrm{NO}_{x}$ to $\mathrm{N}_{2}$ in both the ferrihydrite enrichments.

Potential Feammox rates were conservative estimates calculated from ${ }^{30} \mathrm{~N}_{2}$ production rate alone. ${ }^{5}$ It was estimated that Feammox rates were $0.11 \mathrm{mg} \mathrm{N} \mathrm{L}^{-1}$ day $^{-1}$ in both DIRB enrichments, which were comparable to those calculated in tropical soils (approximately $0.32 \mathrm{mg} \mathrm{N} \mathrm{L}^{-1}$ day $^{-1}$ ), intertidal wetlands (0.24-0.36 $\mathrm{mg} \mathrm{N} \mathrm{L}^{-1}$ day $\left.^{-1}\right)$, and paddy soils (0.17$0.59 \mathrm{mg} \mathrm{N} \mathrm{L}^{-1}$ day $\left.^{-1}\right){ }^{4-6}$

Effect of Electron Shuttles on Feammox. Amendment of the electron shuttles (AQDS and biochar) in DIRB enrichments significantly stimulated the rates and extent of Feammox (Feammox rate were $0.13-0.46 \mathrm{mg} \mathrm{N} \mathrm{L}^{-1} \mathrm{day}^{-1}$ ) and $\mathrm{Fe}$ (II) production (Figures 1 and 2). Moreover, the effect on Feammox (Feammox rate was $0.28-0.48 \mathrm{mg} \mathrm{N} \mathrm{L}^{-1}$ day $^{-1}$ ) and $\mathrm{Fe}(\mathrm{II})$ production rate and extent were further enhanced when both AQDS and biochar were added (Figures 1 and 2). It was likely ascribed to the accumulation of quinone compounds contained by AQDS and biochar; also, the capacity of biochar to adsorb the $\mathrm{Fe}$ (II) might lead to a faster iron(III) reduction rate in the ferrihydrite enrichments. ${ }^{16,51}$ This further indicated the impact of electron shuttles on Feammox-based $\mathrm{N}$ loss from the enrichments. When both ${ }^{29} \mathrm{~N}_{2}$ and ${ }^{30} \mathrm{~N}_{2}$ are taken into consideration, the utilization of ${ }^{15} \mathrm{NH}_{4}^{+}$was increased $4.1-11.5 \%$ in the two DIRB enrichments when electron shuttles were added. These results suggested that electron shuttles played a pivotal role in anaerobic $\mathrm{NH}_{4}{ }^{+}$oxidation, a fact that is often overlooked in the estimation of $\mathrm{N}$ loss in humic-rich environments. The trend of total $\mathrm{NH}_{4}^{+}$consumption further supported this conclusion (Figure S1). In addition, although biochar was reported to be a useful additive to agricultural land to modify soil quality and increase crop yields, ${ }^{25}$ it should be carefully considered given that biochar application may cause higher Feammox-mediated $\mathrm{N}$ loss. The properties of biochar are affected by the feedstock, treatment temperature, and even particle sizes. ${ }^{37-40}$ Interestingly, no significant enhancement in rate and extent of Feammox and iron(III) reduction was observed in the ex situ ferrihydrite enrichment amended with larger particle size $(2 \mathrm{~mm})$ of biochar (data not shown). Therefore, more studies will still be needed to better understand the effect of different properties of biochar on Feammox.

The $\mathrm{pH}$ was ranged from 6.8-7.2 during the experiment (Figure S3), suggesting that the direct oxidation of ammonium to $\mathrm{N}_{2}$ is the only feasible pathway according to the theoretical equations.

However, the change in the concentrations of $\mathrm{NO}_{3}{ }^{-}$ and $\mathrm{NO}_{2}^{-}$and headspace of $\mathrm{N}_{2} \mathrm{O}$ production indicated that Feammox-dependent denitrification and chemodenitrification may make a contribution to the $\mathrm{N}_{2}$ production (Figures $\mathrm{S} 1$ and S4). This may be due to the difference between the theoretical reactions and actual reactions. The amount of total $\mathrm{N}_{2} \mathrm{O}$ was significantly $(P<0.05)$ lower than that of ${ }^{15} \mathrm{~N}-\mathrm{N}_{2}$, and the ${ }^{45} \mathrm{~N}_{2} \mathrm{O}$ and ${ }^{46} \mathrm{~N}_{2} \mathrm{O}$ were under the detection limit (Figures 1 and $\mathrm{S} 4$ ). Electron shuttles amendments increased the amount total $\mathrm{N}_{2} \mathrm{O}$, which is the end or intermediate product of denitrification and chemodenitrification (Figure S4). ${ }^{18,20,25}$ There was a significant $(P<0.05)$ increase in the abundances of denitrification-related functional genes (nirK, nirS, and nosZ) in the electron-shuttleamended enrichments, especially the biochar amendments (Figure S5A-C). Among these genes, nirK and nirS encode nitrite reductase and the nos $\mathrm{Z}$ encodes $\mathrm{N}_{2} \mathrm{O}$ reductase. ${ }^{25}$ It was thus deduced that denitrification was enhanced by the addition of electron shuttles, which was consistent with other studies about the effect of biochar and AQDS on denitrification in the environments. ${ }^{52,53}$ These may explain the change in the $\mathrm{NO}_{3}{ }^{-}$ and $\mathrm{NO}_{2}^{-}$concentrations in both of the ferrihydrite enrichments. The enhanced expression of nos $Z$ provides evidence for the further reduction of $\mathrm{N}_{2} \mathrm{O}$ to $\mathrm{N}_{2}$ (Figure S5C). ${ }^{25}$ Additionally, the abundance of anammox-related functional gene $(h z s B)^{41}$ was also increased significantly $(P<0.05)$ by AQDS and biochar (Figure S5D). In brief, these results suggested that electron shuttles may also stimulate the Feammox-based denitrification and anammox to increase the loss of $\mathrm{N}$ in the enrichments. It was worth noting that the production of ${ }^{29} \mathrm{~N}_{2}$ and ${ }^{30} \mathrm{~N}_{2}$ contributed to $13.2-35.7 \%$ of total $\mathrm{NH}_{4}{ }^{+}$consumption, which was higher than the sum of ${ }^{15} \mathrm{~N}-\mathrm{N}_{2}$ production and $\mathrm{NO}_{3}{ }^{-}$and $\mathrm{NO}_{2}^{-}$production in both the ferrihydrite enrichments (Figures 1 and $\mathrm{S} 1$ ). This may be due to the fact that part of $\mathrm{NH}_{4}^{+}$was utilized as the $\mathrm{N}$ source for microbial growth (synthesis of acid amino and protein). ${ }^{54}$

Fe(III) Reduction Involved in Feammox and Dissimilatory Iron(III) Reduction in the Ferrihydrite Enrichments. ${ }^{30} \mathrm{~N}_{2}$ was used to estimate the proportion of $\mathrm{Fe}(\mathrm{II})$ formation associated with Feammox. It was indicated that only a minor proportion of iron(III) reduction was coupled with ammonium oxidation, while most of the produced $\mathrm{Fe}$ (II) was considered to be coupled with organic matter oxidation and increased with the addition of electron shuttles (Figure 2 and Table S5 and S7). This conclusion was supported by the significant $(P<0.05)$ relative abundance of known acetateoxidizing, dissimilatory iron(III)-reducing bacteria detected from both enrichments (Table S8). It is evident that the amendment of electron shuttling compounds stimulated both Feammox process and acetate-oxidizing dissimilatory iron(III) reduction (Figures 1-3and S6 and Table S9). This is 
particularly important in acidic soils, in which organic carbon levels are often very low and amorphous $\mathrm{Fe}$ (III) (oxyhydr)oxide minerals are rich. ${ }^{4}$ Thus, application of electron shuttles such as biochar may reduce the soil fertility by reducing $\mathrm{N}$ and organic carbon levels in acidic soils. In addition, a proportion of produced $\mathrm{Fe}(\mathrm{II})$ was ascribed to the abiotic $\mathrm{Fe}$ (III) reduction by AQDS, biochar, or both (Figure 2 and Table S5), which agreed with the previous studies. ${ }^{16}$ Siderite $\left(\mathrm{FeCO}_{3}\right)$ and vivianite $\left(\mathrm{Fe}_{3}\left(\mathrm{PO}_{4}\right)_{2}\right)$ may form in the ferrihydrite enrichments and natural environments. ${ }^{16,50}$ It was estimated that the energy yielded may decrease if insoluble siderite $\left(\mathrm{Fe}^{2+}+\mathrm{CO}_{3}{ }^{2-} \rightarrow\right.$ $\left.\mathrm{FeCO}_{3} \quad \Delta_{\mathrm{r}} G_{\mathrm{m}}=+10.17 \mathrm{~kJ} \mathrm{~mol}^{-1}\right)$ and vivianite $\left(3 \mathrm{Fe}^{2+}+\right.$ $\left.2 \mathrm{PO}_{4}{ }^{3+}+8 \mathrm{H}_{2} \mathrm{O} \rightarrow \mathrm{Fe}_{3}\left(\mathrm{PO}_{4}\right)_{2} \cdot 8 \mathrm{H}_{2} \mathrm{O} \Delta_{\mathrm{r}} G_{\mathrm{m}}=+71.21 \mathrm{~kJ} \mathrm{~mol}^{-1}\right)$ formed followed with Feammox in soils (see the Supporting Information). Therefore, the other elements in soils may affect Feammox, which needs further study in future.

The rate of increase in iron(III) reduction extent by two electron shuttles was different between the ex situ ferrihydrite and in situ ferrihydrite enrichments (Table S9). These differences may be related to the enrichment of iron(III)-reducing bacteria selected by different electron shuttles and different forms of ferrihydrite in two enrichments (Figure 4 and Table S8). Table S8 summarized the relative abundance of iron(III)reducing bacteria in both ferrihydrite enrichments. The five most-abundant genera were Geobacter, Anaeromyxobacter, Desulfosporosinus, Dechloromonas, and Geothrix. ${ }^{42,43}$ Fermentative, iron-reducing bacteria related to Pelobacteraceae ${ }^{44}$ were also detected from each treatment (Table S8). In the treatments without electron shuttles, Geobacter predominated the bacterial community and was more abundant in the in situ ferrihydrite enrichment compared to the ex situ ferrihydrite enrichment (Table S8). Moreover, it was worth noting that the different extent of increase in the Feammox was observed in the ex situ ferrihydrite and in situ ferrihydrite enrichments amended with the same electron shuttles (AQDS or biochar) (Figure 1 and Table S9). These might be attributed to the additional salts contained in the in situ ferrihydrite enrichment and thus lead to different solution conductivity between the enrichments. Also, the in situ ferrihydrite formation procedure might lead to an incorporation of other elements (e.g., $\mathrm{P}, \mathrm{Ni}$, $\mathrm{Al}$, and Se from the medium) into the structure that would affect the reactivity of the mineral. Interestingly, amendment with electron shuttles was shown to significantly $(P<0.05)$ shift the predominant bacteria from Geobacter and Anaeromyxobacter to unclassified Pelobacteraceae (Figure 4 and Table S8). From the same ferrihydrite enrichment, a significant $(P<0.05)$ difference in the abundance of the unclassified Pelobacteraceae was shown between the biochar amendment and AQDS amendment results, which corresponded to the varying extent of iron(III) reduction in the two enrichments (Figure 4 and Table S8). Additionally, the genus Geobacter was more abundant in the in situ ferrihydrite enrichment than in the ex situ ferrihydrite enrichment, which could explain the higher rate of iron(III) reduction in the in situ ferrihydrite enrichment (Figure 2B,D). The genus Desulfosporosinus was only significantly increased in the ex situ ferrihydrite enrichment amended with biochar, AQDS, and both, respectively. All of these differences may result in the dissimilar extent of dissimilatory iron(III) reduction in both enrichments. Moreover, correlation analysis indicated that the ratio of increase in Feammox was significantly $(P<0.05)$ correlated with that of dissimilatory iron(III) reduction under amendment with the same electron shuttle (AQDS or biochar) in the in situ ferrihydrite enrichments but not in the ex situ ferrihydrite enrichments (Table S9). This warrants further investigation and the isolation of functional Feammox bacteria to better understand the mechanism of Feammox in the future.

Feammox-Related Microbes. ${ }^{30} \mathrm{~N}_{2}$ was only produced in the biotic treatments, indicating that the microbes mediated Feammox. Feammox rates (as measured by ${ }^{30} \mathrm{~N}_{2}$ production rates) were shown to be strongly correlated with the rates of acetate consumption and iron(III) reduction (Figures 1-3, S6, and S7), suggesting that Feammox probably co-occurred with acetate-oxidizing DIRB. This is supported by the ubiquitous presence of Feammox in terrestrial ecosystems that are abundant in $\mathrm{Fe}(\mathrm{III})$ (oxyhydr)oxides and present alongside DIRB. $^{7-9}$ Both the iron(III) reduction rates and ${ }^{30} \mathrm{~N}_{2}$ production rates were significantly $(P<0.05)$ related to the bacterial abundances of Geobacter (positive correlation in the $\mathrm{CK}$ but negative correlation in the electron shuttle amendments) and unclassified Pelobacteraceae (positive correlation in the electron shuttles amendments) in both enrichments (Table S10). Although we could not identify the functional Feammox bacteria directly, this correlation might provide microbial evidence for the importance of iron(III)-reducing bacteria in the co-occurrence of Feammox. Iron(III)-reducing bacteria are reported to affect Feammox by controlling $\mathrm{Fe}(\mathrm{III})$ reduction in anaerobic environments. ${ }^{6}$ The addition of AQDS and biochar significantly stimulated the growth of bacteria and archaea, especially the iron-reducing bacteria (Figure 4 and Tables S8 and S11). It is well-documented that addition of extracellular quinone is a strategy for stimulating $\mathrm{Fe}(\mathrm{III})$ reduction in many environments. ${ }^{33} \mathrm{Fe}$ (III) reducers such as Geobacter can reduce the quinone to the hydroquinone state linked with acetate oxidation, and the hydroquinone can then abiotically reduce $\mathrm{Fe}(\mathrm{III}){ }^{43,45}$ Quinone compounds act as electron shuttles for many organisms, including those may not reduce iron(III) on their own, and thus increase the likelihood of electron transfer to $\mathrm{Fe}(\mathrm{III}){ }^{16,46}$ To this end, we have confirmed our hypothesis that the addition of electron shuttles in the form of quinone facilitated ammonium oxidation to $\mathrm{N}_{2}$ and was mediated by Feammox bacteria capable of $\mathrm{Fe}$ (III) reduction.

The abundance of putative denitrifiers, including Rhodoplanes, Bacillus, Acinetobacter, Pseudomonas, Corynebacterium, Propionibacterium, Agrobacterium, Pseudoxanthomonas, and Sinorhizobium, ${ }^{47}$ significantly increased when amended with electron shuttles, especially biochar (Table S11), which was consistent with the effect of electron shuttles on denitrification and anammox gene abundance in our study and previous reports. ${ }^{52,53}$ This further suggested that Feammox to $\mathrm{NO}_{2}{ }^{-}$and $\mathrm{NO}_{3}{ }^{-}$followed by denitrification might contribute to the enhancement of $\mathrm{N}_{2}$ production in the enrichments. Furthermore, Van Trump et al. suggested that a diverse set of microorganisms may be capable of oxidizing quinone coupled to nitrate reduction in soils. ${ }^{35,38}$ In our study, several iron(III)reducing bacteria (Geobacter and Geothrix) are also capable of using nitrate as an electron acceptor, ${ }^{43,48}$ which may lead to the reduction of nitrate to nitrite and ultimately dinitrogen. ${ }^{12,49}$ However, almost no known anammox bacteria were detected in both enrichments with all treatments, which was likely due to the extremely low abundance of anammox bacteria.

In summary, it was demonstrated that electron shuttles (AQDS and biochar) stimulated Feammox and DIR, and a further enhancement was observed when these two electron shuttles were combined. Amendments with electron shuttles 
increased Feammox activity, resulting in more $\mathrm{N}$ loss, and also contributed to a shift in the microbial communities, including the $\mathrm{Fe}(\mathrm{III})$-reducing microbes and denitrifiers. We propose that natural humic substances or the artificial addition of biochar could enhance the risk of $\mathrm{N}$ fertilizer loss via Feammox from the environment. This study provides new insights into $\mathrm{N}$ cycling in paddy soils and warrants extensive investigation of Feammox processes at different scales under different environmental conditions.

\section{ASSOCIATED CONTENT}

\section{S Supporting Information}

The Supporting Information is available free of charge on the ACS Publications website at DOI: 10.1021/acs.est.6b02077.

Additional details on quantitative PCR and calculation of the thermodynamic favorability of siderite and vivianite formation. Figure $\mathrm{S} 1$ : The concentrations of $\mathrm{NH}_{4}^{+}$, $\mathrm{NO}_{2}^{-}$and $\mathrm{NO}_{3}^{-}$in both the ferrihydrite enrichments amended with AQDS, biochar, and AQDS + biochar. Figure S2: The concentrations of total iron in both the ferrihydrite enrichments amended with AQDS, biochar, and AQDS + biochar. Figure S3: Changes of $\mathrm{pH}$ in both the ferrihydrite enrichments amended with AQDS, biochar, and AQDS + biochar. Figure S4: Headspace $\mathrm{N}_{2} \mathrm{O}$ production in both the ferrihydrite enrichments amended with AQDS, biochar, and AQDS + biochar. Figure S5: Gene copy numbers of nirK, nirS, $n o s Z$, and $h z s B$ genes in both the ferrihydrite enrichments amended with AQDS, biochar, and AQDS + biochar. Figure S6: Relationship between iron(III) reduction rates and acetate reduction rates in both the ferrihydrite enrichments amended with AQDS, biochar, and AQDS + biochar. Figure S7: Relationship between Feammox rate and acetate reduction rate in both the ferrihydrite enrichments amended with AQDS, biochar, and AQDS + biochar. Table S1: Physicochemical properties of the biochar. Table S2: Basic properties of soil. Table S3: Ratios of increase in the extent of $\mathrm{N}_{2}\left({ }^{30} \mathrm{~N}_{2}\right.$ and $\left.{ }^{29} \mathrm{~N}_{2}\right)$ production and iron(III) reduction in both the ferrihydrite enrichments amended with AQDS, biochar, and AQDS + biochar after a 30 day incubation. Table S4: Ratios of ${ }^{29} \mathrm{~N}_{2}$ and ${ }^{30} \mathrm{~N}_{2}$ in both the ferrihydrite enrichments amended with AQDS, biochar, and AQDS + biochar. Table S5: The ratios of ferrous iron associated with Feammox or dissimilatory iron(III) reduction (DIR) in both the ferrihydrite enrichments amended with AQDS, biochar, and AQDS + biochar. Table S6: The numbers of OTU and sequence for each sample in treatments in both the ferrihydrite enrichments. Table S7: The amount of acetate consumption in both the ferrihydrite enrichments amended with AQDS, biochar, and AQDS + biochar after 30 days. Table S8: The average relative abundances of iron(III)-reducing bacteria in both the ferrihydrite enrichments amended with AQDS, biochar, and AQDS + biochar. Table S9: The rate of increase in Feammox and dissimilatory iron(III) reduction (DIR) in both the ferrihydrite enrichments amended with AQDS, biochar, and AQDS + biochar. Table S10: Pearson correlation between iron(III)-reducing bacteria abundances and ${ }^{30} \mathrm{~N}_{2}$ production rates and iron(III) reduction rates. Table S11: The abundances of bacterial and archaeal 16S rRNAin both the ferrihydrite enrichments amended with AQDS, biochar, and AQDS + biochar after 30 day incubation. Table S12: The average relative abundances of denitrifiers in both the ferrihydrite enrichments amended with AQDS, biochar, and AQDS + biochar. (PDF)

\section{AUTHOR INFORMATION}

\section{Corresponding Author}

*Phone: +86-592-6190560; fax: +86-6190977; e-mail: xryang@ iue.ac.cn.

\section{Notes}

The authors declare no competing financial interest.

\section{ACKNOWLEDGMENTS}

This work was supported by the National Natural Science Foundation of China (41430858), the Strategic Priority Research Program of Chinese Academy of Sciences (XDB15020302 and XDB15020402), and the International Science \& Technology Cooperation Program of China (2011DFB91710).

\section{REFERENCES}

(1) Vitousek, P. M.; Howarth, R. W. Nitrogen limitation on land and in the sea. Biogeochemistry 1991, 13, 87-115.

(2) Galloway, J. N.; Townsend, A. R.; Erisman, J. W.; Bekunda, M.; Cai, Z.; Freney, J. R.; Martinelli, L. A.; Seitzinger, S. P.; Sutton, M. A. Transformation of the nitrogen cycle: recent trends, questions, and potential solutions. Science 2008, 320 (5878), 889-892.

(3) Long, A.; Heitman, J.; Tobias, C.; Philips, R; Song, B. Cooccurring anammox, denitrification, and codenitrification in agricultural soils. Appl. Environ. Microbiol. 2013, 79 (1), 168-176.

(4) Ding, L. J.; An, X. L.; Li, S.; Zhang, G. L.; Zhu, Y. G. Nitrogen loss through anaerobic ammonium oxidation coupled to iron reduction from paddy soils in a chronosequence. Environ. Sci. Technol. 2014, 48 (18), 10641-10647.

(5) Yang, W. H.; Weber, K. A.; Silver, W. L. Nitrogen loss from soil through anaerobic ammonium oxidation coupled to iron reduction. Nat. Geosci. 2012, 5 (8), 538-541.

(6) Li, X.; Hou, L.; Liu, M.; Zheng, Y.; Yin, G.; Lin, X.; Cheng, L.; Li, $\mathrm{Y}$.; $\mathrm{Hu}, \mathrm{X}$. Evidence of nitrogen loss from anaerobic ammonium oxidation coupled with ferric iron reduction in an intertidal wetland. Environ. Sci. Technol. 2015, 49 (19), 11560-11568.

(7) Shrestha, J.; Rich, J. J.; Ehrenfeld, J. G.; Jaffe, P. R. Oxidation of ammonium to nitrite under iron-reducing conditions in wetland soils: Laboratory, field demonstrations, and push-pull rate determination. Soil Sci. 2009, 174 (3), 156-164.

(8) Sawayama, S. Possibility of anoxic ferric ammonium oxidation. J. Biosci. Bioeng. 2006, 101 (1), 70-72.

(9) Clement, J.; Shrestha, J.; Ehrenfeld, J.; Jaffe, P. Ammonium oxidation coupled to dissimilatory reduction of iron under anaerobic conditions in wetland soils. Soil Biol. Biochem. 2005, 37 (12), 23232328.

(10) Lovley, D. R.; Coates, J. D.; Blunt-Harris, E. L.; Phillips, E. J. P.; Woodward, J. C. Humic substances as electron acceptors for microbial respiration. Nature 1996, 382 (6590), 445-448.

(11) Piepenbrock, A.; Behrens, S.; Kappler, A. Comparison of humic substance-and $\mathrm{Fe}(\mathrm{III})$-reducing microbial communities in anoxic aquifers. Geomicrobiol. J. 2014, 31 (10), 917-928.

(12) Coates, J. D.; Cole, K. A.; Chakraborty, R.; O'Connor, S. M.; Achenbach, L. A. Diversity and ubiquity of bacteria capable of utilizing humic substances as electron donors for anaerobic respiration. Appl. Environ. Microbiol. 2002, 68 (5), 2445-2452.

(13) Roden, E. E.; Kappler, A.; Bauer, I.; Jiang, J.; Paul, A.; Stoesser, R.; Konishi, H.; Xu, H. Extracellular electron transfer through microbial reduction of solid-phase humic substances. Nat. Geosci. 2010, 3 (6), 417-421. 
(14) Kappler, A.; Benz, M.; Schink, B.; Brune, A. Electron shuttling via humic acids in microbial iron(III) reduction in a freshwater sediment. FEMS Microbiol. Ecol. 2004, 47 (1), 85-92.

(15) Jiang, J.; Kappler, A. Kinetics of microbial and chemical reduction of humic substances: implications for electron shuttling. Environ. Sci. Technol. 2008, 42 (10), 3563-3569.

(16) Kappler, A.; Wuestner, M. L.; Ruecker, A.; Harter, J.; Halama, M.; Behrens, S. Biochar as an electron shuttle between bacteria and $\mathrm{Fe}(\mathrm{III})$ minerals. Environ. Sci. Technol. Lett. 2014, 1 (8), 339-344.

(17) Spott, O.; Russow, R.; Stange, C. F. Formation of hybrid $\mathrm{N}_{2} \mathrm{O}$ and hybrid $\mathrm{N}_{2}$ due to codenitrification: first review of a barely considered process of microbially mediated N-nitrosation. Soil Biol. Biochem. 2011, 43 (10), 1995-2011.

(18) Jones, L. C.; Peters, B.; Lezama Pacheco, J. S.; Casciotti, K. L.; Fendorf, S. Stable isotopes and iron oxide mineral products as markers of chemodenitrification. Environ. Sci. Technol. 2015, 49 (6), 34443452.

(19) Kumon, Y.; Sasaki, Y.; Kato, I.; Takaya, N.; Shoun, H.; Beppu, T. Codenitrification and denitrification are dual metabolic pathways through which dinitrogen evolves from nitrate in streptomyces antibioticus. J. Bacteriol. 2002, 184 (11), 2963-2968.

(20) Brons, H. J.; Hagen, W. R.; Zehnder, A. J. B. Ferrous iron dependent nitric oxide production in nitrate reducing cultures of Escherichia coli. Arch. Microbiol. 1991, 155, 341-347.

(21) Lovley, D. R.; Phillips, E. J. P. Novel mode of microbial energy metabolism organic carbon oxidation coupled to dissimilatory reduction of iron or manganese. Appl. Environ. Microbiol. 1988, 54 (6), 1472-1480.

(22) Cornell, R.; Schwertmann, U. The Iron Oxides; VCH Verlag: Weinheim, Germany, 1996.

(23) Kappler, A.; Straub, K. L. Geomicrobiological cycling of iron. Rev. Mineral. Geochem. 2005, 59 (1), 85-108.

(24) Klueglein, N.; Kappler, A. Abiotic oxidation of Fe(II) by reactive nitrogen species in cultures of the nitrate-reducing $\mathrm{Fe}(\mathrm{II})$ oxidizer Acidovorax sp. BoFeN1 - questioning the existence of enzymatic Fe(II) oxidation. Geobiology 2013, 11 (2), 180-190.

(25) Xu, H. J.; Wang, X. H.; Li, H.; Yao, H. Y.; Su, J. Q.; Zhu, Y. G. Biochar impacts soil microbial community composition and nitrogen cycling in an acidic soil planted with rape. Environ. Sci. Technol. 2014, 48 (16), 9391-9399.

(26) Molstad, L.; Dörsch, P.; Bakken, L. R. Robotized incubation system for monitoring gases $\left(\mathrm{O}_{2}, \mathrm{NO}, \mathrm{N}_{2} \mathrm{O}\right.$ and $\left.\mathrm{N}_{2}\right)$ in denitrifying cultures. J. Microbiol. Methods 2007, 71 (3), 202-211.

(27) Conrad, R.; Klose, M.; Claus, P. Phosphate inhibits acetotrophic methanogenesis on rice roots. Appl. Environ. Microbiol. 2000, 66 (2), $828-831$.

(28) Ren, G.; Zhang, H.; Lin, X.; Zhu, J.; Jia, Z. Response of phyllosphere bacterial communities to elevated $\mathrm{CO}_{2}$ during rice growing season. Appl. Microbiol. Biotechnol. 2014, 98 (22), 94599471.

(29) Xu, H. J.; Li, S.; Su, J. Q.; Gibson, V.; Li, H.; Zhu, Y. G.; Nie, S. Does urbanization shape bacterial community composition in urban park soils? A case study in 16 representative Chinese cities based on the pyrosequencing method. FEMS Microbiol. Ecol. 2014, 87 (1), 182192.

(30) Su, J. Q.; Wei, B.; Ou-Yang, W. Y.; Huang, F. Y.; Zhao, Y.; Xu, H. J.; Zhu, Y. G. Antibiotic resistome and its association with bacterial communities during sewage sludge composting. Environ. Sci. Technol. 2015, 49 (12), 7356-7363.

(31) Wang, Q.; Garrity, G. M.; Tiedje, J. M.; Cole, J. R. Naive Bayesian classifier for rapid assignment of rRNA sequences into the new bacterial taxonomy. Appl. Environ. Microbiol. 2007, 73 (16), 5261-5267.

(32) Price, M. N.; Dehal, P. S.; Arkin, A. P. FastTree: computing large minimum evolution trees with profiles instead of a distance matrix. Mol. Biol. Evol. 2009, 26 (7), 1641-1650.

(33) Tunney, M. M.; Einarsson, G. G.; Wei, L.; Drain, M.; Klem, E. R.; Cardwell, C.; Ennis, M.; Boucher, R. C.; Wolfgang, M. C.; Elborn, J. S. Lung microbiota and bacterial abundance in patients with bronchiectasis when clinically stable and during exacerbation. Am. J. Respir. Crit. Care Med. 2013, 187 (10), 1118-1126.

(34) Brunner, B.; Contreras, S.; Lehmann, M. F.; Matantseva, O.; Rollog, M.; Kalvelage, T.; Klockgether, G.; Lavik, G.; Jetten, M. S. M.; Kartal, B.; Kuypers, M. M. Nitrogen isotope effects induced by anammox bacteria. Proc. Natl. Acad. Sci. U. S. A. 2013, 110 (47), 18994-18999.

(35) Sigman, D. M.; Casciotti, K. L.; Andreani, M.; Barford, C.; Galanter, M.; Böhlke, J. K. A bacterial method for the nitrogen isotopice analysis of nitrate in seawater and freshwater. Anal. Chem. 2001, 73 (17), 4145-4153.

(36) Casciotti, K. L.; Sigman, D.; Hastings, M. G.; Boehlke, J. K.; Hilkert, A. Measurement of the oxygen isotopic composition of nitrate in seawater and freshwater using the denitrifier method. Anal. Chem. 2002, 74 (19), 4905-4912.

(37) Spokas, K. A.; Reicosky, D. C. Impacts of sixteen different biochars on soil greenhouse gas production. Ann. Environ. Sci. 2009, 3, 179-193.

(38) Cantrell, K. B.; Hunt, P. G.; Uchimiya, M.; Novak, J. M.; Ro, K. $\mathrm{S}$. Impact of pyrolysis temperature and manure source on physicochemical characteristics of biochar. Bioresour. Technol. 2012, 107, 419-428.

(39) Zhao, L.; Cao, X.; Masek, O.; Zimmerman, A. Heterogeneity of biochar properties as a function of feedstock sources and production temperatures. J. Hazard. Mater. 2013, 256-257, 1-9.

(40) Sigua, G. C.; Novak, J. M.; Watts, D. W.; Cantrell, K. B.; Shumaker, P. D.; Szogi, A. A.; Johnson, M. G. Carbon mineralization in two ultisols amended with different sources and particle sizes of pyrolyzed biochar. Chemosphere 2014, 103, 313-321.

(41) Yang, X. R.; Li, H.; Nie, S. A.; Su, J. Q.; Weng, B. S.; Zhu, G. B.; Yao, H. Y.; Gilbert, J. A.; Zhu, Y. G. Potential contribution of anammox to nitrogen loss from paddy soils in Southern China. Appl. Environ. Microbiol. 2015, 81 (3), 938-947.

(42) Ding, L. J.; Su, J. Q.; Xu, H. J.; Jia, Z. J.; Zhu, Y. G. Long-term nitrogen fertilization of paddy soil shifts iron-reducing microbial community revealed by $\mathrm{RNA}^{-13} \mathrm{C}$-acetate probing coupled with pyrosequencing. ISME J. 2015, 9 (3), 721-734.

(43) Esther, J.; Sukla, L. B.; Pradhan, N.; Panda, S. Fe(III) reduction strategies of dissimilatory iron reducing bacteria. Korean J. Chem. Eng. 2015, 32 (1), 1-14.

(44) Hori, T.; Aoyagi, T.; Itoh, H.; Narihiro, T.; Oikawa, A.; Suzuki, K.; Ogata, A.; Friedrich, M. W.; Conrad, R.; Kamagata, Y. Isolation of microorganisms involved in reduction of crystalline iron(III) oxides in natural environments. Front. Microbiol. 2015, 6, 386.

(45) Snoeyenbos-West, O. L.; Nevin, K. P.; Anderson, R. T.; Lovley, D. R. Enrichment of Geobacter species in response to stimulation of $\mathrm{Fe}(\mathrm{III})$ reduction in sandy aquifer sediments. Microb. Ecol. 2000, 39 (2), 153-167.

(46) Röling, W. F. The family Geobacteraceae. In The Prokaryotes; Springer: New York, 2014; pp 157-172.

(47) Shapleigh, J. P. The denitrifying prokaryotes. Prokaryotes 2006, $2,769-792$.

(48) Lovley, D. R. Dissimilatory Fe(III)- and Mn(IV)-reducing prokaryotes. Prokaryotes 2006, 2, 635-658.

(49) Van Trump, J. I.; Wrighton, K. C.; Thrash, J. C.; Weber, K. A.; Andersen, G. L.; Coates, J. D. Humic acid-oxidizing, nitrate-reducing bacteria in agricultural soils. mBio 2011, 2 (4), e00044.

(50) Walpersdorf, E.; Koch, C. B.; Heiberg, L.; O’Connell, D. W.; Kjaergaard, C.; Hansen, H. C. B. Does vivianite control phosphate solubility in anoxic meadow soils? Geoderma 2013, 193-194, 189199.

(51) Mosley, L. M.; Willson, P.; Hamilton, B.; Butler, G.; Seaman, R. The capacity of biochar made from common reeds to neutralise $\mathrm{pH}$ and remove dissolved metals in acid drainage. Environ. Sci. Pollut. Res. 2015, 22 (19), 15113-15122.

(52) Harter, J.; Weigold, P.; El-Hadidi, M.; Huson, D. H.; Kappler, A.; Behrens, S. Soil biochar amendment shapes the composition of $\mathrm{N}_{2} \mathrm{O}$-reducing microbial communities. Sci. Total Environ. 2016, 562, 379-390. 
(53) Harter, J.; Krause, H. M.; Schuettler, S.; Ruser, R.; Fromme, M.; Scholten, T.; Kappler, A.; Behrens, S. Linking $\mathrm{N}_{2} \mathrm{O}$ emissions from biochar-amended soil to the structure and function of the N-cycling microbial community. ISME J. 2014, 8 (3), 660-74.

(54) Sanchez, S.; Demain, A. L. Metabolic regulation of fermentation processes. Enzyme Microb. Technol. 2002, 31, 895-906. 